\title{
Mean platelet volume as a biomarker of the risk and prognosis of coronary artery disease
}

\author{
Hany Ahmad Mohammed*Asmaa A. Abdel baset* MohammedEzzat \\ Amin*Mahmoud Gaber Mahmoud* \\ *Department of Internal Medicine, Sohag University
}

Mean platelet volume has been reported as potential tool in predicting patients who may develop coronary artery disease after primary percutaneous intervention. ${ }^{1}$ Clinical assessment of MPV is ongoing. Currently, three lines of evidence suggest that it is potentially a clinically useful biomarker for risk stratification of patients who may develop coronary artery disease after PCI. First, several studies have addressed the frequencies of impaired reperfusion, left ventricular systolic dysfunction, and mortality in patients with acute myocardial infarction (AMI) who have undergone primary PCI or thrombolysis. ${ }^{2,3}$ Second, some studies have shown that MPV is a useful predictive marker of short- and long-term clinical outcomes in unselected PCI cohorts, regardless of whether the patients had undergone elective or primary PCI. ${ }^{4}$ Third, some reports have suggested that MPV, or changes in it over time, reflect high residual platelet reactivity after conventional dual antiplatelet therapy in patients who have undergone PCI. ${ }^{5}$

\section{Mean platelet volume as a biomarker for acute myocardial infarction}

Acute myocardial infarction occurs due to coronary atherosclerosis as well as thrombosis. ${ }^{1}$ When atherosclerotic plaque ruptures or erode, platelets are recruited to the exposed subendothelial region and the partially occluded vessels become completely occluded with the new formed thrombus. Large platelets have greater thrombotic potential and are biologically more potent. ${ }^{6}$ Increased platelet volume has been shown to be more reactive with greater production of thromboxane A2 and serotonin. Studies have reported platelet volume to be significantly higher among acute myocardial infarction patients than control subjects. ${ }^{7,8}$

An elevated MPV correlates with poor clinical outcomes among survivors of myocardial infarction in the era of thrombolysis and an impaired response to thrombolysis in those with ST segment elevated myocardial infarction. ${ }^{9}$ MPV is also a strong independent predictor of impaired angiographic reperfusion, in-hospital major adverse cardiovascular events, and 30-day, 6-month, 12-month, and 2-year mortality from STEMI treated via primary PCI. ${ }^{10,11,12}$ In addition, a higher MPV on admission is independently associated with impaired microvascular perfusion, a poor postintervention myocardial blush grade, decreased post-PCI thrombolysis, and a poorer myocardial infarction flow grade (thrombolysis in myocardial infarction [TIMI]) in STEMI patients treated via primary PCI. ${ }^{12,13,14}$

In one study, a higher MPV on admission was strongly associated with greater microvascular resistance, a steeper diastolic deceleration time, a lower thermodilution-derived coronary flow reserve, and a higher coronary wedge pressure. ${ }^{14} \mathrm{MPV}$ seems to play a role in mediating reperfusion injury. In patients with STEMI scheduled for PCI, MPV at admission may be a valuable discriminator of a higher-risk patient subgroup, and a useful guide when deciding whether adjunctive therapy may be necessary to improve outcomes. ${ }^{15}$

Mean platelet volume as prognostic tool in percutaneous coronary intervention outcome 
MPV has been reported as a useful biomarker in early identification of patients with stable coronary artery disease at high risk of post-PCI low-reflow. Studies have shown that pre-procedural elevated MPV is associated with the incidence of major adverse cardiac event and restenosis following PCI. ${ }^{16}$ The study submitted that MPV is a potential marker of restenosis after PCI. Another study reported that MPV independently predicted post-PCI-corrected thrombolysis in myocardial infarction frame count. ${ }^{17}$ Similar to the effects of MPV on AMI, several studies have found that an elevated MPV is a strong independent predictor of long-term outcomes after PCI. ${ }^{4,18}$ However, one study found that mortality increased when the MPV rose over time after PCI, but the pre-procedural MPV was not predictive in this context. ${ }^{19}$ It was suggested that monitoring MPV after PCI might aid in risk classification.

\section{Mean platelet volume and residual platelet interference in dual antiplatelet therapy}

Antiplatelet therapy reduces the incidence of both procedure-related complications and ischemic cardiovascular events after PCI. ${ }^{20}$ Particularly, dual antiplatelet therapy (aspirin and an ADP receptor inhibitor) is the present standard of care after implantation of drug-eluting stents. Nevertheless, high residual platelet reactivity can limit the utility of antiplatelet therapy, increasing the frequency of cardiovascular events both during the procedure and during long-term follow-up. ${ }^{21,22}$

However, Paulu et al., ${ }^{23}$ in a prospective observational study, showed that clopidogrel resistance was not of prognostic utility in an unselected cohort of 378 patients who underwent PCI. In addition, Collet et al., ${ }^{24}$ observed no significant improvement in clinical outcomes when platelet function was monitored and adjusted in patients who underwent coronary stenting, compared to those who received standard antiplatelet therapy (without monitoring); this was a large, randomized open-label study on 2,440 patients.

Platelet activity testing can be time-consuming, expensive, and technically complex. ${ }^{25}$ However, MPV can be readily measured before PCI using automated hematology analyzers. Recently, Kim et al., ${ }^{26}$ suggested that a high MPV was associated with reduced responses to aspirin and clopidogrel. Some investigators have suggested that an increase in MPV over time after PCI is associated with high ontreatment platelet reactivity. ${ }^{5}$ Moreover, Choi et al. ${ }^{4}$ suggested that MPV was superior to platelet function testing in terms of predicting cardiac death or cardiovascular events in patients who had undergone PCI, particularly those in an acute coronary syndrome subgroup.

\section{Limitations}

MPV can be simply and inexpensively determined and does not require professional interpretation. However, there are several limitations to using MPV as an indicator of heart disease. This is because most relevant studies have been retrospective in nature, enrolled small numbers of patients, or had confounding factors that may have affected platelet volume. ${ }^{27}$ Furthermore, a wide range of cut-off values has been used in retrospective

studies, emphasizing that prospective works are needed.

\section{Conclusions}

Many studies have shown associations between an elevated MPV and poor clinical outcomes after PCI in patients with coronary artery disease. The marker also affords valuable insights into how to identify patients at high risk for coronary artery disease after PCI, and provides useful guidance as to when additional adjunctive therapy 
is needed to improve clinical outcomes.

\section{References}

1. Jorgensen KA, Dyerberg J. Platelets and atherosclerosis. A review on the role of platelets in atherosclerosis with special reference to the role of polyunsaturated 20 carbon. Dan Med Bull 1980;27:253-9.

2. Huczek Z, Kochman J, Filipiak KJ, Horszczaruk GJ, Grabowski M, Piatkowski R, Wilczynska J, Zielinski A, Meier B, Opolski G. Mean platelet volume on admission predicts impaired reperfusion and long-term mortality in acute myocardial infarction treated with primary percutaneous coronary intervention. J Am CollCardiol 2005;46:284-290.

3. Wang XY, Yu HY, Zhang YY, Wang YP, Feng XH, Li ZP, Du XJ, Gao W. Serial changes of mean platelet volume in relation to Killip Class in patients with acute myocardial infarction and primary percutaneous coronary intervention. Thromb Res 2015;135:652-658.

4. Choi SW, Choi DH, Kim HW, Ku YH, Ha SI, Park G. Clinical outcome prediction from mean platelet volume in patients undergoing percutaneous coronary intervention in Korean cohort: implications of more simple and useful test than platelet function testing. Platelets 2014;25:322- 327.

5. Koh YY, Kim HH, Choi DH, Lee YM, Ki YJ, Kang SH, Park G, Chung JW, Chang KS, Hong SP. Relation between the change in mean platelet volume and clopidogrel resistance in patients undergoing percutaneous coronary intervention. CurrVascPharmacol 2015;13:687693.

6. Agrawal BK, Manchanda B, Garg A, Mittal A, Mahajan NC, Agrawal U. Mean platelet volume in acute myocardial infarction: a case-control study. J Cardiovasc Res 2015;1:4.

7. Khode V, Sindhur J, Kanbur D, Nallulwar S. Mean platelet volume and the platelet volume indices in patient with stable coronary artery disease and acute myocardial infarction: a case-control study. J Cardiovasc 2012;3: 272-6.

8. Chu SG, Becker RC, Berger PB, Bhatt DL, Eikelboom JW, Konkle B, Mohler ER, Reilly MP, Berger JS. Mean platelet volume as a predictor of cardiovascular risk: a systematic review and meta-analysis. $\mathbf{J}$ ThrombHaemost 2010;8: 148-56.

9. Pereg D, Berlin T, Mosseri M. Mean platelet volume on admission correlates with impaired response to thrombolysis in patients with STelevated myocardial infarction. Platelets 2010;21:117-21.

10. Lekston A, Hudzik B, Hawranek M, Szkodzinski J, Gorol J, Wilczek K, Gasior M, Polonski L. Prognostic significance of mean platelet volume in diabetic patients with ST-elevation myocardial infarction. J Diabetes Complications 2014;28:652-657.

11. Cakici M, Cetin M, Balli M, Akturk E, Dogan A, Oylumlu M, Abus S, Yildiz E, Sungur A, Celiker M. Predictors of thrombus burden and no-reflow of infarct-related artery in patients with ST-segment elevation myocardial infarction: importance of platelet indices. Blood Coagul Fibrinolysis 2014;25:709-715.

12. Lai HM, Chen QJ, Yang YN, Ma YT, Li XM, Xu R, Zhai H, Liu F, Chen BD, Zhao Q. Association of mean platelet volume with impaired myocardial reperfusion and shortterm mortality in patients with STsegment elevation myocardial infarction undergoing primary percutaneous coronary intervention. Blood Coagul Fibrinolysis 2016;27:512.

13. Elbasan Z, Gur M, Sahin DY, Kuloglu O, Icen YK, Turkoglu C, Ozkan B, Uysal OK, Kalkan GY, Çaylı M. Association of mean platelet volume and pre- and postinterventional flow with infarctrelated artery in ST-segment elevation myocardial infarction. Angiology 2013;64:440-446.

14. Sezer M, Okcular I, Goren T, Oflaz $\mathrm{H}$, Nisanci Y, Umman B, Mercanoglu $\mathrm{F}$, Bilge AK, Meric M, Umman S. Association of haematological indices 
with the degree of microvascular injury in patients with acute anterior wall myocardial infarction treated with primary percutaneous coronary intervention. Heart 2007;93:313-318.

15. Maden $O$, Kacmaz F, Selcuk $H$, Selcuk MT, Aksu T, Tufekcioglu O, Senen EK, Balbay Y, Ilkay E. Relationship of admission hematological indexes with myocardial reperfusion abnormalities in acute ST segment elevation myocardial infarction patients treated with primary percutaneous coronary interventions. Can J Cardiol 2009;25:e164-e168.

16. Yang A, Pizzulli I, Luderitz B. Mean platelet volume as marker of restenosis after percutaneous transluminal coronary angioplasty in patients with stable and unstable angina pectoris. Thromb Res 2016;117:371-7.

17. Duygu H, Turkoglu C, Kirilmaz B, Turk U. Effects of mean platelet volume on post-intervention coronary blood flow in patients with chronic stable angina pectoris. J Invasive Cardiol 2017;20:120-4.

18. Goncalves SC, Labinaz M, Le May M, Glover C, Froeschl M, Marquis JF, O'Brien E, Shukla D, Ruchin P, Sookur D, Ha A, So D. Usefulness of mean platelet volume as a biomarker for long-term outcomes after percutaneous coronary intervention. Am J Cardiol 2011;107:204-209.

19. Shah B, Oberweis B, Tummala L, Amoroso NS, Lobach I, Sedlis SP, Berger JS. Mean platelet volume and long-term mortality in patients undergoing percutaneous coronary intervention. Am J Cardiol 2013;111:185-189.

20. Shanker J, Gasparyan AY, Kitas GD, Kakkar VV. Platelet function and antiplatelet therapy in cardiovascular disease implications of genetics polymorphisms. CurrVascPharamacol 2011;9:479-89.

21. Snoep JD, Hovens MM, Eikenboom $\mathrm{JC}$, van der Bom JG, Jukema JW, Huisman MV. Clopidogrelnonresponsiveness in patients undergoing percutaneous coronary intervention with stenting: a systematic review and meta-analysis. Am Heart J 2007;154:221-231.

22. Bonello L, Pansieri M, Mancini J, Bonello R, Maillard L, Barnay $\mathrm{P}$, Rossi P, Ait-Mokhtar O, Jouve B, Collet F, Peyre JP, Wittenberg O, de Labriolle A, Camilleri E, Cheneau E, Cabassome E, Dignat-George F, Camoin-Jau L, Paganelli F. High ontreatment platelet reactivity after prasugrel loading dose and cardiovascular events after percutaneous coronary intervention in acute coronary syndromes. J Am CollCardiol 2011;58:467-473.

23. Paulu $P$, Osmancik $P$, Tousek $P$, Minarik M, Benesova L, Motovska Z, Bednar F, Kocka V, Widimsky P. Lack of association between clopidogrel responsiveness tested using point- of-care assay and prognosis of patients with coronary artery disease. J Thromb Thrombolysis 2013;36:1-6.

24. Collet JP, Cuisset T, Range G, Cayla G, Elhadad S, Pouillot C, Henry P, Motreff P, Carrié D, Boueri Z, Belle L, Van Belle E, Rousseau H, Aubry P, Monségu J, Sabouret P, O'Connor SA, Abtan J, Kerneis M, SaintEtienne C, Barthélémy $\mathrm{O}$, Beygui $\mathrm{F}$, Silvain J, Vicaut E. Bedside monitoring to adjust antiplatelet therapy for coronary stenting. N Engl J Med 2012;367:2100-2109.

25. Michelson AD. Methods for the measurement of platelet function. Am J Cardiol 2009;103(3 Suppl):20A26A.

26. Kim YG, Suh JW, Yoon $\mathrm{CH}$, Oh IY, Cho YS, Youn TJ, Chae IH Choi DJ. Platelet volume indices are associated with high residual platelet reactivity after antiplatelet therapy in patients undergoing percutaneous coronary intervention. $\mathrm{J}$ AtherosclerThromb 2017;21:445- 453.

27. Leader A, Pereg D, Lishner M. Are platelet volume indices of clinical use? A multidisciplinary review. Ann Med 2012;44:805-816. 